\title{
Transactions of the Burgon Society
}

Volume 2

Article 4

$1-1-2002$

\section{Who may wear the 'Literate's Hood'?}

Nicholas Groves

Follow this and additional works at: https://newprairiepress.org/burgonsociety

\section{Recommended Citation}

Groves, Nicholas (2002) "Who may wear the 'Literate's Hood'?", Transactions of the Burgon Society. Vol. 2. https://doi.org/10.4148/2475-7799.1008

This Article is brought to you for free and open access by New Prairie Press. It has been accepted for inclusion in Transactions of the Burgon Society by an authorized administrator of New Prairie Press. For more information, please contact cads@k-state.edu. 


\title{
WHO MAY WEAR THE 'LITERATE'S HOOD'?
}

\author{
Nicholas Groves, Dean of Studies
}

I have enclosed the words 'literate's hood' in inverted commas as I do not entirely believe in such an animal. The wording of the famous Canon is 'a decent tippett of black, so it be not silk', and I am not entirely persuaded that a 'tippett' is a hood. However, common usage has led to its being so defined, and thus it deserves discussion. (I leave it to another to define when, why and how the 'tippett' became a hood).

We need to start, I think, by defining what a hood is used for, and the simple answer is that it is used to define the status of one's membership within a corporation. Despite current practice, whereby each degree is seen as a discrete qualification, in the manner of A-levels, the original meaning of a degree was to mark one's membership at bachelor or master/doctor level within a faculty - but not necessarily, I suspect, within any particular university; the hoods associated with the degrees meant 'This chap is a member [of this university] at doctor level in the Faculty of Divinity.' Indeed, the earliest hoods of Oxford and Cambridge (there is room for discussion over St Andrew's, Glasgow and Aberdeen!) seem to have been identical - Doctors of Laws, for example, at both universities wore scarlet and pink. Hoods were (and indeed are) used by corporations such as the Livery Companies to signify membership, and some recently-founded societies use them in precisely this manner - 'this chap is a member of our club at Fellow level'. At some point in the nineteenth century, there is a shift of perception, and each degree is seen as discrete - thus it is possible, these days, to graduate as BA in English, and then as BA in German in the same university, and claim one has two BAs! ${ }^{1}$ The academic hood then comes to signify a certain amount of study completed.

For those clergy who were not members of a university, the 'decent tippett' was prescribed. ${ }^{2}$ This was, I think, a garment of dignity, marking their status as Clerks in Holy Orders, rather than an indication that they had studied privately; other clergy wore their hoods primarily as marks of dignity, not to 'parade their learning'. ${ }^{3}$ Again, during the nineteenth century, there is a change of perception, and the 'tippett', by now a hood ${ }^{4}$, has come to mark study completed, and non-graduate clergy who attended a theological college wear distinctive hoods. Some of the first such hoods were striking: St Bees (fnd 1816, the first such college) originally (until 1866) used a black hood lined inside with white in the left side and red in the right side ${ }^{5}$ Chichester (fnd 1839) had a black hood, lined violet and bound with fur; Truro (fnd 1877) a black hood trimmed with grey rabbit fur. These hoods were quietened down in 1882, when they were restricted to a black stuff hood with a narrow border of coloured silk. But some colleges were intended for graduates only, and did not prescribe a hood, and such non-graduates as did attend them used the plain black hood. ${ }^{6}$ Thus the 'literate's hood' comes to mark successful completion of a course of theological study for which no specific academical hood is awarded.

${ }^{1}$ My case is interesting: I 'have' two MAs, but from different universities. I suppose technically I 'have' only one, but satisfied requirements to be admitted at MA level to the second university (of which I was already a bachelor anyway...).

${ }^{2}$ Facetiously, I often wonder what an indecent tippett might look like...

${ }^{3}$ An all-too-frequent excuse for not wearing one.

${ }^{4}$ There is also the possibility that it is founded on the non-regent MA Cantab hood, which was black silk, unlined.

${ }^{5}$ At least one $\mathrm{C} 19$ bishop directed some ordinands wearing this St Bees hood to 'take those things off'! It was replaced by a hood lined with violet.

${ }^{6}$ I suspect it may have got mixed up with the plain black unlined stuff hood of the Arts undergraduate at Oxford, still in use in the mid-C19. See Hargreaves-Mawdsely, p 98 
The logical extension of this is that anyone taking any course which does not have its own hood may wear the plain black hood. Indeed, Basil Minchin, in his book Outward and Visible, ${ }^{7}$ says that 'the plain black hood is the mark of the scholar, and ... the qualification to wear it has been defined as the ability to sign one's name'. I am not sure I would go so far, but obviously there must be a cut-off point: but where do we put it? A public examination? In which case, A-level? O-level/CSE/GCSE? Any of these is as logical as any other suggestion.

Is it therefore appropriate to non-theological non-graduates? I have often urged non-graduate colleagues in schools who wanted to wear a hood to acquire one (that is, those who couldn't be bothered to do a part-time degree), and I think this was justified; teachers are, if at a long remove, still historically 'clerks', even if not in holy orders. Many non-graduate Readers also use the black hood, again, appropriately, I think, as having theological training. And I suppose therefore we must allow it to Chartered Accountants, Members of the Royal Pharmaceutical Society, Associates of the Institute of Banking, Diplomates of the Architectural Association... ${ }^{8}$ : all have studied, and thus qualify as 'clerks'.

But, and it is a 'big but', the form of the hood is important. Objections are frequently made against having it made it the [f1] shape, as it looks too much like the BD Cantab: $;^{9}$ using the [s1] or [s2] shapes obviates this - as indeed would the [a1] shape, which would be a very dignified garment. But the real point is that the hood must be unlined: black stuff lined black stuff (as they are commonly made) is, in whatever shape, not a 'literate's hood'. It happens not to be anything at all (at present), but the true literate's hood can only be made without a lining. ${ }^{10}$ The BDs of Oxford, Cambridge, Dublin and Durham are all of black silk lined with black silk; remove the lining and it is not a BD. ${ }^{11}$

I shall finish with a provocative point. Certain students at Oxford, who were allowed to read for the BCL without first completing the BA, were known as 'Students in Civil Law' (SCL). ${ }^{12}$ They were allowed to wear a plain, unlined blue hood. It is arguable that this is the true Arts undergraduate hood - the black hood used by Arts undergraduates and BAs being in fact borrowed from Divinity. Thus, anyone who wishes to wear a literate's hood, and is not theologically qualified, ought perhaps to wear, not a black, but a blue unlined stuff hood, in one of the simple shapes.

\section{"Academical Dress of Music Colleges and Societies of Musicians in the United Kingdom with notes on Degrees and Diplomas in Music of certain other Institutions"}

by Nicholas Groves and John Kersey

This booklet gives an authoritative account of the robes of as many colleges and societies as can be discovered - including many now closed. It also gives details of obsolete robes. Also included are brief histories of the institutions concerned, with details of mergers and re-namings. There are four pages of colour plates, illustrating several of the hoods and robes. Published by The Burgon Society, 2002. Price $£ 3.50$ inc. p\&p.

Orders to the Treasurer, The Burgon Society, Weyhill House, Weyhill, Hants; SP11 OPP with a cheque for payable to The Burgon Society.

\footnotetext{
${ }^{7}$ Darton, Longman \& Todd, 1961; p 234

8 ... and I am sure someone will tell me all these have hoods anyway these days!

${ }^{9}$ Indeed, a certain robemaker sells the same hood indifferently as BD Cantab and as the literate's hood.

${ }^{10}$ The post-1882 theological college hoods were unlined with a narrow border - see above.

${ }^{11}$ Again, nor is it anything else, though in [f1] shape it might be the old non-regent MA of Cambridge.

${ }^{12}$ Cambridge had them too, but they wore the BA robes.
} 